\title{
ELABORATION OF THE METHOD OF OBTAINING THE PRODUCTS FOR THE CULTIVATION OF FLOWER PRODUCTION WITH ANTIMICROBIAL COVERING
}

\section{Sorokina Svetlana ${ }^{1}$ \\ Akmen Vyktorya ${ }^{2}$}

DOI: http://dx.doi.org/10.30525/978-9934-571-26-8_18

Abstract. The purpose of the research paper is the elaboration of the method of obtaining products for the cultivation of flower products with antimicrobial covering. The method of obtaining the developed components of glutinous mixtures for antimicrobial fungal covering allows offering the way of their applying and obtaining new products which can be used for diseases prevention and treating in hothouses plants during their cultivation. Methodology. Since significant proportion of pathogens can enter the root system of in hothouses plants precisely when they are transplanted, the working hypothesis is advanced; it is in the providing of accessories and flowerpots with the ability to show prophylactic and therapeutic action against pathogens of fungal and microbial diseases of potted plants by treating their surface with disinfectant mixture. The implementation of the hypothesis is carried out by selecting of the mixture components, which have an effective action, don't have significant affect on the product price increasing and can be used in the technological process of flower and decorative goods producing without significant changes. It is facilitated by a wide range of systemic disinfectants which are presented on the market and own researches about their actions.

We have formed and scientifically grounded new ways of improving the consumer properties of products belonging to the group of flower and decorative products on the base of the theoretical and experimental researches of the study physical and mechanical and aesthetic indices of flower pots and accessories quality. Proposed ways are based on the technology of manufacturing ceramic pots and accessories for flowers with additional con-

${ }^{1}$ Candidate of Technical Sciences, Associate Professor,

Kharkiv State University of Food Technology and Trade, Ukraine

${ }^{2}$ Candidate of Technical Sciences, Associate Professor,

Kharkiv State University of Food Technology and Trade, Ukraine 
sumer properties, which are exhibited by the application of antimicrobial covering - a glutinous mixture which contains glue (on the base of flour, starch, etc.) and solution of substances which provide prophylaxis and plant protection against microbial and fungal diseases. The composition of the antimicrobial covering, the concentration of components and the duration of its action were experimentally determined. Methods of applying antimicrobial covering to a number of products for cultivating and decorating in hothouses plants (solid and striped) are proposed depending on the type of glue substance. It is established that antimicrobial covering does not affect on the processed products quality indices which were defined according to the normative standards.

The absence of microbiological damage of the covering membrane is proved; the dynamics of microbiological contamination of the soil, the inhibition of fungal diseases development and the plants decorative properties improvement were experimentally confirmed on the example of flowering plants - Cyclamen and Begonia x elatior due to the microbiological research.

Thus, the composition of the antimicrobial glutinous mixture and its method of application to the products which are used for cultivating of flower products were developed and proposed; it allowed the consumer properties increasing and obtaining new products with antimicrobial covering.

\section{Introduction}

Floriculture and design with use of flowers and flower accessories are the most developed sectors of the national economy, which bring significant profit, in most countries of the world. Recently, this trend is developing at a rapid pace, especially in Europe.

Exterior design of houses, private plots, parks, interiors of habitable and office premises with souvenirs, natural and artificial flowers, which are placed in bright pots and decorated with a number of accessories, serving as separate complement and design accent is traditional for Ukraine as a European country, and also based on national habits of the population. Now practically all companies and trading networks offer to decorate flower compositions or gift sets with bright and colorful accessories which are suitable for seasonal subjects or human nature. That is why they became good sources of income for various Ukrainian and foreign companies. However, with the development of market economy, there is an intensification of the struggle for the consumer both in the Ukrainian 
and foreign markets in this sector; it requires the intensification of scientific research, the implementation of new ideas and developments into the production and the use of new competitive products. In this regard, the formation and improvement of consumer properties of floral and decorative goods allow creation of new opportunities for their application and preservation of quality during operation, and accordingly provide increasing of competitive advantages over analogues.

New tendencies of improvement of the consumer properties of products which belong to the group of flower and decorative products are formed and scientifically substantiated on the base of theoretical and experimental researches of physical and mechanical and aesthetic indices study of flower pots and accessories quality. The proposed tendencies are related to the technology of manufacturing ceramic pots for flowers with additional consumer properties, which are manifested by the application of antimicrobial covering - glutinous mixture with the content of substances which promote the prevention and protection of plants from microbial and fungal diseases. The composition of the antimicrobial covering, the concentration of components and the duration of its action were experimentally determined. Methods of applying antimicrobial covering to a number of products for cultivating and decorating in hothouses plants are proposed depending on the type of glue substance. It is established that antimicrobial covering does not affect on the processed products quality indices which were defined according to the normative standards.

The absence of microbiological damage of the covering membrane is proved; the dynamics of microbiological contamination of the soil, the inhibition of fungal diseases development and the plants decorative properties improvement were experimentally confirmed on the example of flowering plants - Cyclamen and Begonia x elatior due to the microbiological research.

\section{Market trends and consumer properties improving of flower and decorative goods (products)}

In the 21 st century, new wave of growing interest in flower pots and accessories was appeared in Europe and America as a serious complementing and emphasizing means for flower composition. The largest flower shops began to actively engage in the cooperation small things enterprises; it would emphasize the beauty of indoor plants and the appearance of pri- 
vate plots. At the same time, the Ukrainian market of flower products annually grows by $20-25 \%$ [1-3].

The local production of accessories is not sufficiently developed in our country, therefore, this market largely depends on imports, where significant proportion is counterfeit products, its share can reach one third of the total market volume. Official importers are mostly Western European countries (France, Czech Republic, Germany, and Italy); their share is under 28\%. However, Ukrainian enterprises try to win their place on the market every year and equalize the shares of Ukrainian, Russian, European and "Eastern" products in the sales volumes of flower accessories in Ukraine [4].

In general, over the past few years, there were three main trends in the market of ceramic pots and other decorative ceramic products. First, cheap products are still in high demand and in 2016 its share has decreased slightly. Secondly, despite the rather low demand for local products in Ukraine, the Ukrainian producer continued to increase production volumes by expanding the range and developing chamotte raw materials. Thirdly, Ukraine continues to increase the volume of imports of these goods from virtually all countries-producers and in all price segments. Fourth, the Ukrainian consumer is ready to introduce new developments for increasing the competitiveness of their products. Thus, the assortment of the Ukrainian market of flower and decorative products and accessories for their cultivation is not saturated yet and will continue to increase.

At the same time, the development of the market is impossible under the presence of goods which don't meet the quality and a number of consumer properties such as functional, ergonomic, aesthetic characteristics of the copyright model, the ceramics properties and compliance with the technological process [5-8]. An important index is the microbiological stability of pottery materials and other flower accessories. That is, it is the new introduction to the formation of quality and a number of consumer properties will provide the competitiveness of local producers in the market of flower and decorative products.

The developments of scientists V. Ignatenko, V. Vohmyanina, G. Ivanova, brothers Makarov in the field of increasing the consumer properties of accessories and flower pots are known, where much attention is paid to constructive devices to pots for setting up and automation of plants watering and nutrition [9-16]. Flowers pots with design which allows preventing injury or poisoning of children and animals as a result of contact 
with plants are elaborated [17]. At present, there are a number of developments which concern new constructions, raw materials cost reducing, equipping with automatic fertilizer and irrigation devices, and other methods for improving the quality and properties of ceramic products [18-20]. The pots with improved container-devices are suggested for facilitating the formation of the plant during its growth [21] or where flowers are planted in the openings between the upper and lower parts [22; 23]. A number of works are devoted to conducting studies of assortment and quality indices of flower and decorative ceramic pots of local and foreign producers is known [24; 25]. According to the results of these works, it is established that a large proportion of the products fully corresponds to the standardized quality parameters, but they are usual means for cultivating and decorating in hothouses plants, it indicates the necessity to continue the researches for providing products with new properties.

The analysis shows that in conditions of fierce competition, the actual task for scientists is not only to control the quality of ceramic pots for flowers, but also to develop new solutions for improving the consumer properties of ceramic pots for flowers by providing them with additional functional potential and it will provide the competitiveness increasing of products of this group.

\section{Effect of diseases on the formation of potted plants properties}

Pests and pathogens, as well as diseases of physiological (non-parasitic) and infectious (fungi, bacteria, viruses, nematodes) origin, which significantly affect on general state of plants, sometimes cause their death, damage considerably of flower and decorative products. The development of harmful and pathogenic organisms is facilitated by the environmental conditions of the premises: light and temperature conditions are not always optimal and excessive air dryness is often observed. Insufficient or excessive watering, improperly selected earth mixtures, unbalanced nutrition, draughts, gas pollution and other conditions increase the influence of negative factors. Plants under proper care differ not only in high decorative, but also show increased resistance to disease, less susceptible to pest attacks [26]. It should be noted that the pathogenic fungi are the causative agents of most of the diseases of the in hothouses plants, only some of them affect on plants leaves; others cause the extinction of branches and trunks [27].

Anthracnose is quite widespread disease of indoor plants, causative agents of which are pathogenic fungi of deuteromycetes - Phylosticta, Col- 
letotrichum, Ceratocystis, Septoria, Kabatiella, Gloeosporium and many others. The reason of rotting and/or roots and root necks wilt (for rosettelike plants such as African violets) is affection by soil fungi such as Cylindrocladium, Fusarium, Phytophtora, Pythium, Rhizoctonia and many others. Among the fungi Fusarium oxesporum should be marked out, it causes vascular wilt, is one of the most common diseases of potted plants. Yellowing of leaves, their twisting and drying are signs of this disease [28; 29].

For today, systems of measures for the protection of plants against pests and diseases are developed for various types of open ground and in hothouses plants, these measures include preventive (agrotechnical, selective, quarantine) and exterminative (chemical, biological, mechanical) methods of control, which mutually complement each other [30]. Fungicides and bactericides are main among chemical agents for the protection of potted flowers in closed premises, they completely (fungicidal) or partially (fungistatic) inhibit the development of pathogens of plant diseases and now they are actively used for pest control $[31 ; 32]$.

The necessity of use the measures for prevention and prophylaxis of plant infections by fungal and microbial diseases during their growth is conditioned by the fact that significant percentage of soil mixtures which are presented in the Ukrainian market may contain fungal germs of certain diseases at the time of their selling because of non-compliance with storage conditions. The young plants which are firstly planted in pot with soil the most sensitive to the infection contamination. It is difficult for an inexperienced consumer to choose necessary disinfectant, in addition, there is not always time for its purchasing and preparation for use, and sometimes just careless attitude causes the plant death. Therefore, the development of such products and means of control and prevention of diseases, where system addition to the soil of disinfectants occurs mediated indirectly from the actions of plant owner and provides neutralization the fungi germs of the most common diseases becomes topical problem.

\section{Hypothesis of antimicrobial covering elaboration on products for flower products cultivating}

The studies of consumer properties of floral and decorative products, namely, pots for their cultivation show that although local producers' products meet the requirements of regulatory documentation on organoleptic and physical and chemical indices for this type of product, but are inferior 
to imported products of the same name on the decorative design quality. Foreign producers also win due to the availability of larger material base, which updates the need to develop and implement new scientific advances for solving the problem of the industry. Thus, the problem of improving the consumer properties of goods for cultivating and decorating in hothouses plants arises in conditions of fierce competition.

According to scientific research and a number of literary sources significant factor in the formation of new consumer properties and, accordingly, the quality of pots for the cultivation in hothouses plants is the possibility of creating medium which provides protection or prevents the emergence and reproduction of fungal and microbial diseases. Under this condition the important factor is the lack of influence on the organoleptic and physical and chemical indices of quality as of new products and on the growth and development of decorative properties of the plant directly.

Since significant proportion of pathogens can fall into the root system of in hothouses plants precisely under their transplanting, the working hypothesis is advanced, it is in the possibility to provide pots for flowers cultivation with ability to exhibit prophylactic and therapeutic action for controlling pathogens of fungal and microbial diseases of potted plants by treating their surface with disinfectant mixture. Implementation of the hypothesis is possible in the conditions of selection of mixture components, which will have an effective action, not significantly affect the product price increasing and can be used in the technological process of producing flower and decorative goods without significant changes. It is facilitated by a wide range of systemic disinfectants which are available on the market and the results of own researches about their action.

The proposed working hypothesis with taking into account the above mentioned can be transformed into an innovative strategy for the introduction of the final technological operation for the processing of flower accessories and containers for the cultivation of in hothouses plants with specially prepared disinfectant mixtures in the solution of astringent which provide the prevention of fungal diseases. And from the goal achieving standpoint the implementation of the components of the innovation strategy is, mainly, for obtaining the plants with good decorative properties under the lack of their cultivation experience.

The ways and methods by which the application of the disinfecting mixture is possible: covering the inside surface of boxes for bulbous flowering 
plants cultivation; covering the surface of flowers accessories which have contact with the soil; covering the inside surface of ceramic pots for flowers cultivation are proposed on the base of assortment of flower and decorative goods which are directly interconnected with the soil or parts of the plants during their cultivation.

It is assumed on the base of the theory of gradual solubility of certain types of glutinous solutions that the applied on flower and decorative product membrane which contains the decontamination solution gradually dissolves and the solution substrate gradually passes to the soil with each plant watering. In this way, the gradual decontamination and protection of the soil will occur.

The tasks of the presented in this paper research include the substantiation and selection of components for the disinfection mixture, the choose of the method of applying it to selected research objects and confirming of the pots' consumer properties increasing for the cultivation of plants obtained with the application of the proposed technological stage; confirmation of the effectiveness of the action and the gradual transition of disinfectants into the soil by conducting its microbiological research and observing the change in the aesthetic properties of the experimental plants.

\section{Elaboration of the antimicrobial covering composition and methods of its use}

The research is aimed at developing the composition of the antimicrobial covering and studying the ways of its applying to ceramic products for proving the hypothesis of the possibility of manufacturing the pots, which apart from their main purpose, would have additional consumer properties, namely the ability to neutralize pests in the soil and prevent fungal diseases. Samples of ceramic pots, water soluble glue substances and decontamination solutions were selected as objects for further research [33]. The studies were conducted in several stages. At the first stage, work was devoted to the development of an antimicrobial mixture of fungicide and water soluble astringent, which was applied to the walls of ceramic pots, and exhibited after placing in pots of soil and plants its neutralization effect under plants' watering for a long time. At the second stage, the absence of changes in the quality of the pots with antimicrobial covering and their shelf life were determined. At the third stage, the effectiveness of the selected mixture was checked through microbiological analysis. 
At the beginning, water solution of potatoes starch paste was chosen as glue agent, because of its ability to gradual dissolution in water, starch safety for plants and low cost. Systemic fungicide "Phytosporin-M" was chosen as a solution for treating pots for prevention microbiological and fungal diseases of plants [34]. The preparation "Phytosporin-M" was prepared by dissolving 0,5 liters of water at $20^{\circ} \mathrm{C}$ according to the instructions; then starch paste was prepared by dissolving it in the prepared solution "Phytosporin-M", with its further brewing, in three concentrations: liquid 2: 1 , medium cream-like 7:1, ointment-like 10:1. The ratio of starch and water 7:1 was chosen experimentally as the optimum consistency, which made it possible to obtain cream-like consistency of paste. Such paste under drying firmly fixes on the surface without cracking and splashing. The layer of astringent $-1.5 \ldots 2 \mathrm{~mm}$ is experimentally determined; it quickly hardens, minimizes the appearance of cracks and provides good adhesion with pot's crock. In addition, such thickness should be resistant to swelling and not provide significant nutrient medium for the development of microbes, molds, etc., but it required experimental confirmation.

The experimental samples of the pots were treated by applying of glutinous mixture (potato starch paste and fungicide "Phytosporin-M") along the entire interior surface of the walls (fig. 1) and left for gelling with a periodic (every $10-15 \mathrm{~min}$ ) drying at temperature of $150 \ldots 180^{\circ} \mathrm{C}$.
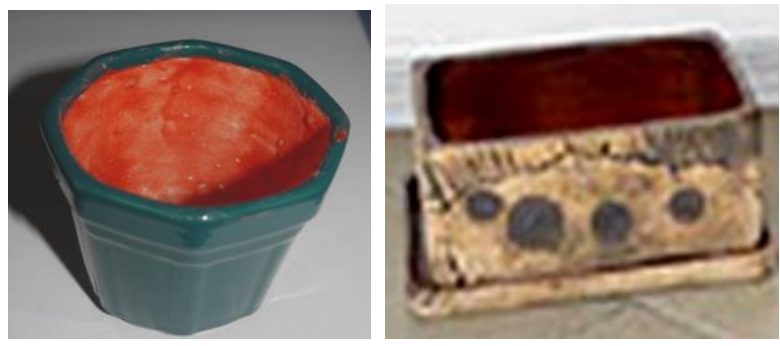

\section{Fig. 1. Ceramic pots with antimicrobial covering of the interior surface}

The pots samples were filled up with usual soil for flowers and it was watered with settled water during 6 months for determining the ability and time of gradual dissolution of the astringent. The quantity of water was selected 
according to known literature data $[35 ; 36]$ about standard watering of in hothouses plants. At the same time, the possibility of dissolving and the presence of astringent on the walls of the pot were determined due to the available color of water, which passed through the thickness of the soil and went through hole at the bottom of the pot. Studies show that glutinous mixture of potato starch paste and fungicide can gradually dissolve under watering the soil during the whole study period, although the color gradually lightens as the paste concentration decreases on the walls of the pot and, consequently, in water.

Since potato starch paste is nutrient medium for the propagation of fungi and yeast spores, and also may be contaminated with potato bacillus spores, a number of studies have been conducted on the development of microbial contamination in the prepared glutinous mixture (the solution of "Phytosporin-M" and starch). The research sample was taken in 12 hours, in a day and in 36 hours after its preparing. The microbiological analysis included standard operations [37]. Studies have shown that after 7 days characteristic colonies formed on the medium of MPA, and they were considered on the dishes with small magnification $(10 \times 10)$ of microscope. The results of the studies were compared with Sanitary Rules and Standards 2.3.21078-01 [38] (table 1).

Table 1

\section{Microbiological indices of potato starch paste and fungicide "Phytosporin-M" during storage $(n=5, P \geq 0,95)$}

\begin{tabular}{|l|l|l|l|l|}
\hline \multirow{2}{*}{\multicolumn{1}{|c|}{ Indices }} & \multicolumn{2}{c|}{$\begin{array}{c}\text { The paste mixture from potato } \\
\text { starch and fungicide }\end{array}$} & \multicolumn{1}{|c|}{$\begin{array}{c}\text { Norms } \\
\text { according to } \\
\text { Sanitary Rules } \\
\text { and Standards }\end{array}$} \\
\cline { 2 - 5 } & $\begin{array}{c}\text { after } \\
\text { 12 hours }\end{array}$ & $\begin{array}{c}\text { after } \\
\mathbf{2 4} \text { hours }\end{array}$ & $\begin{array}{c}\text { after } \\
\mathbf{3 6} \text { hours }\end{array}$ & $\begin{array}{l}\text { not found } \\
\text { not found } \\
\text { allowed }\end{array}$ \\
\hline Escherichia coli & not found & not \\
\hline $\begin{array}{l}\text { Number of mesophilic } \\
\text { aerobic and facultative } \\
\text { anaerobic microorganisms, } \\
\text { CFU/g }\end{array}$ & $4,1 \times 10^{3}$ & $4,7 \times 10^{3}$ & $5 \times 10^{3}$ & $\begin{array}{l}5 \times 10^{3} \mathrm{CFU} / \mathrm{g}, \\
\text { not more }\end{array}$ \\
\hline $\begin{array}{l}\text { Number of fungi spores, } \\
\text { CFU/g }\end{array}$ & 170 & 180 & 195 & $\begin{array}{l}200 \mathrm{CFU} / \mathrm{g}, \\
\text { not more }\end{array}$ \\
\hline $\begin{array}{l}\text { Number of yeast spores, } \\
\text { CFU/g }\end{array}$ & 55 & 100 & 120 & $\begin{array}{l}100 \mathrm{CFU} / \mathrm{g}, \\
\text { not more }\end{array}$ \\
\hline $\begin{array}{l}\text { Number of Bacillus } \\
\text { mesentericus spores, CFU/g }\end{array}$ & $100 \mathrm{CFU/g}$ & $120 \mathrm{CFU} / \mathrm{g}$ & 150 & $\begin{array}{l}\text { Not more than } \\
200 \mathrm{CFU} / \mathrm{g}\end{array}$ \\
\hline
\end{tabular}


As it can be seen from the data of table values of all indices after 12 hours after preparation of suspension from potato starch paste and fungicide are lower than it is allowed by Sanitary Rules and Standards. Moderate increasing of microbiological contamination is observed after 24 hours, but it is within the norm limits, which allows recommending of this term for storage the prepared glutinous mixture of potato starch paste and fungicide "Phytosporin-M", before applying it on the pot surface.

Determining of the pot quality with an antimicrobial covering during storage is the task of further studies. Since the starch and, accordingly, the mixture on its base has high sorption properties, the study of antimicrobial covering humidity was carried out during pots storage. It allows to prove that under thickness of $1,5-2 \mathrm{~mm}$, the humidity of the covering for 9 months is within the recommended limits.

The effect of the antimicrobial mixture (potato starch paste and fungicide "Phytosporin-M") on pot crock porous corking is further studied, it in some way effect on the moisture absorption index (it should be $14-19 \%$ for majolica and pottery products), and according to the index of air permeability, which are important for the development and function of the root system of in hothouses plants. Studies show that the porosity of the crock (according to State Standard 473.3 [39]) of both samples is standard (within $14-19 \%)$ and the use of antimicrobial covering affects on its index insignificantly. Moreover the study showed that after 6 months, the index returns to the previous level, it indicates the washout antimicrobial covering particles. Investigation of the water resistance index of the crock showed that after the application of the antimicrobial covering, the time of the appearance of the wet trace on the side wall of the pot was within the experimental error compared with the control sample. That is, the covering is well soluble in water and does not provide clogging of the crock's natural pores.

Studies of the heat resistance of new pots were carried out in accordance with State Standard 53546-2009 [40] with use of drying oven and thermostat. Studies show that there are hardly noticeable cracks on the surface of the antimicrobial covering in the corner of the products after 6 months of storage which appear at increasing of temperature to $150{ }^{\circ} \mathrm{C}$ and they are permissible for non-food products using.

The microbiological study of pots crock with an antimicrobial covering (from potato starch paste and fungicide "Phytosporin-M") during storage at $18{ }^{\circ} \mathrm{C}$ and humidity of $70 \ldots 75 \%$ determine that all microbiological indices 
after 6 months are within the limits allowed by Sanitary Rules and Standards, which is facilitated by the small thickness of the covering and the low humidity of the pot's crock and the covering membrane (samples were prepared similarly to the above mentioned).

Thus, it is established that pots with antimicrobial covering during 6 months of storage (under air humidity of $70-75 \%$, temperature $18 \pm 2{ }^{\circ} \mathrm{C}$ ) meet the requirements for ordinary ceramic pots.

At the third stage, studies were conducted for proving the effectiveness of the proposed development. For this purpose, the research of the growth and development of the widespread potted plant Begonia $\mathrm{x}$ elatior, which is transplanted into antimicrobial pot (transplantation of the diseased plant together with the soil), was carried out. The choice of plant Begonia x elatior is occurred on the base of the presence of symptoms of powdery mildew (Peronospora parasitica) which is caused by lower fungus Peronospora (the presence of savoyed leaves on one side of the plant, and yellow-green round shape oily spots which are limited by veins on the leaves and gray-violet coat on the underside of leaves) for visualizing the results of external changes under plant cultivation and identifying of the decontamination effect action. The studies were conducted during 16 weeks, with ordinary care and standard watering. The visual observation of plants was accompanied by the sampling of soil for studying the degree of its contamination with fungal diseases, through microbiological research. Selection of soil samples for research was carried out by quartization method with further sifting through sieve with diameter of $3 \mathrm{~mm}$; Then $10 \mathrm{~g}$ of soil was taken, small amount of distilled water was added and it was rubbed to the pastelike state. The dilution 1:10 was done. The grant suspension was treated with use of ultrasound apparatus during 3 minutes, for good dispersion providing before microbiological seeding. Preparation of vivifying medium and sowing were carried out according to the standard method. Surface seeding was carried out on Petri dishes (it is possible to use one method for studying different groups of microorganisms). Sown dishes were incubated during 7 days at temperature of $26^{\circ} \mathrm{C}$ and further studied under microscope magnification $10 \times 10$.

The calculation of isolated Peronospora fungal germs number in the soil was carried out according to the following formula:

$$
a=\frac{b c d}{e}
$$


де $a$ - number of fungal germs in $1 \mathrm{~g}$ of soil; $b$ - the average number of colonies per dishes; $c$ - cultivation from which the inoculation was made; $d$-number of drops in $1 \mathrm{ml}$ of suspension; $e$ - mass of soil taken for analysis, $g$.

The described above microbiological studies were repeated 4 times with periodicity of 3 weeks. Decreasing of Peronospora fungal germs in the soil was observed during that period. The data from fig. 2 confirmed that fact [41].

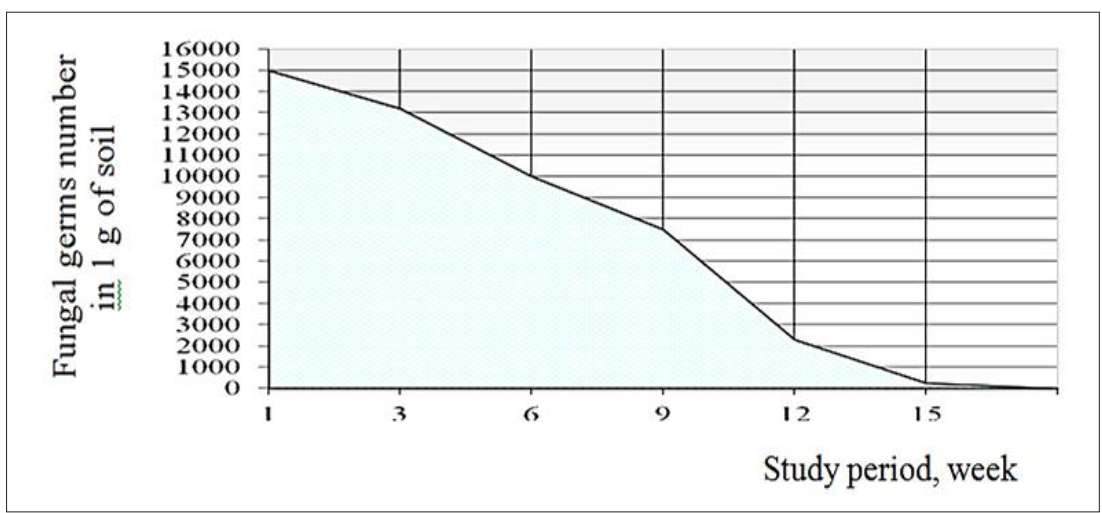

Fig. 2. The dynamics of Peronospora fungal germs number decreasing in the soil

Fig. 2 data show that number of fungal germs decreases after three weeks of watering, then gradual decreasing of fungal contamination was observed every 3 weeks of soil intake and microbiological studies showed that Peronospora fungal germs were almost not identified in $1 \mathrm{~g}$ of soil after 16 weeks. It is satisfactory index for the normal plant development.

The visual observation of the aesthetic and decorative characteristics of the plant Begonia x elatior shows significant improvement of the plant state after ten weeks: gray-violet coat on the underside of leaves disappeared; savoyed leaves had to be removed, but the new shoots of the leaves were healthy, without disease's symptoms.

The conducted studies show the effectiveness of the proposed development and the expedience of use the mixture, which includes potato starch paste and "Phytosporin-M" for application to the walls of ceramic pots for 
obtaining new products with improved consumer properties - pots with antimicrobial covering. New products are able to carry out not only preventive action against the pathogens of plant diseases, but also help to neutralize fungal diseases.

Thus, glue solution with mixture of potato starch paste and fungicide "Phytosporin-M" in ratio of 1:7 is proposed, it is expedient for use as antimicrobial covering for application to the interior surface of flower pots (with layer of $1,5-2 \mathrm{~cm}$ ) and the production of pots with antimicrobial covering with stable consumer properties (microbiological parameters are within the limits allowed by Sanitary Rules and Standards, crock's porosity is at the level of $16-18 \%$, absence of crock's water penetration, humidity of the covering membrane is at the level of $12 \%$ ) during 6 months of storage under conditions of air humidity $70-75 \%$ and temperature of $18 \pm 2{ }^{\circ} \mathrm{C}$.

Series of experiments were carried out for further proving the validity of the hypothesis under conditions of selection of other components for the antimicrobial covering mixture after obtaining positive result of studies the stability of the quality and efficacy of the proposed antimicrobial covering on the base of potato starch and "Phytosporin-M" on the interior surface of ceramic flower pots.

Therefore, the following samples were selected in the further work, as the water-soluble astringent for the development of antimicrobial mixture: 1 - carboxymethylcellulose (CMC), 2 - polyvinyl acetate, 3 - styrene acrylate [29]. The choice of these substances is conditioned by their ecological safety and the ability to form glue astringent solutions which are water soluble, but more resistant to water action compared with starch based paste, and therefore, able to give disinfectant to the soil with plants more longer, which is more rational. Preparation "Fundazol" is selected as solution for prevention microbiological and fungal diseases of plants. The sequence of the main stages of work was similar to the previous one.

Three samples of antifungal action glue mixture with optimal concentration of astringent substance (100 g of CMC per $250 \mathrm{ml}$ of the solution of the preparation "Fundazol", $50 \mathrm{~g}$ of polyvinyl acetate per $25 \mathrm{ml}$ of solution of the preparation "Fundazol" and $30 \mathrm{ml}$ of sterol acrylic per $250 \mathrm{ml}$ of solution of the preparation "Fundazol") were prepared for the research. Water-soluble paint of certain color was added to each sample, which was used as indicator for checking the solubility of used mixture. 
The assumption (hypothesis) about the effectiveness of the antifungal action glue mixtures are prepared on the base of water-soluble astringents under using them on the walls of the pots with non-solid layer, but in the form of strips (fig. 3) arises since the samples of water-soluble astringents are quite expensive. For the realization of the hypothesis, Obtained three samples of the glutinous mixture of antifungal activity were applied to the interior walls of the pots in the form of closed strips with width of $1,5 \mathrm{~cm}$ and thickness of1,5 $-2 \mathrm{~cm}$. The pots were left after application for solidification for 2 days with periodic (every 6 hours) drying at temperature of $150-180{ }^{\circ} \mathrm{C}$ [42]. The thickness of the layer of $1,5-2 \mathrm{~mm}$ was chosen on the base of previous studies, resistance to swelling, index of crack resistance and adhesive properties of the mixture. The index of resistance to microorganisms in the layer of the glue mixture was not taken into account on the base of the absence in the mixture composition of natural nutrient substrate.

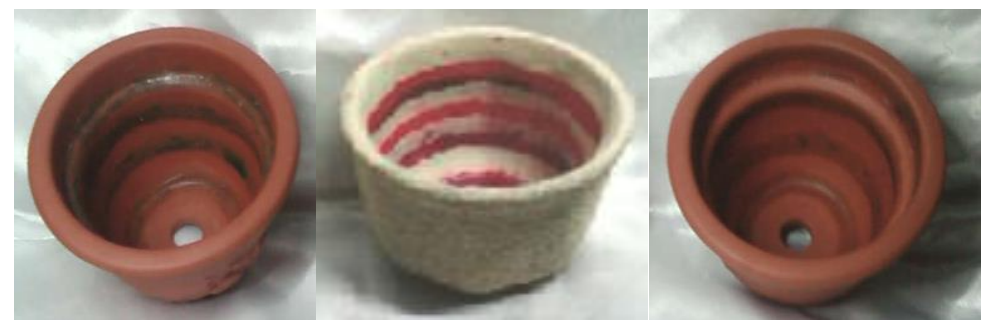

\section{Fig. 3. Ceramic pots with use of antifungal action glutinous mixture}

Soil which was watered by settled water during 6 months, similar to the previous research was introduced into studied pots. Conducted studies ascertain that the glutinous mixture of CMC with "Fundazol" is able to gradually dissolution under watering the soil with water which releases the antifungal preparation "Fundazol". The glue mixture of polyvinyl acetate with "Fundazol" shows weak solubility: the water solution after watering had much lighter color and was coloured for more than 12 months. The third sample of the glutinous mixture remained on the walls of the pot; water under watering was not coloured during the whole study period, it was explained by the formation of membrane which prevented transition of the antifungal agent into the soil. That is why the samples number 2 and 3 were excluded from further researches. 
Further studies were aimed at determining the quality of pots with antifungal covering which was applied according to the economical technology and determination the terms of new products storage. As in previous studies, the effect of antifungal covering on the porosity of the crock has been investigated. It is found that the porosity of the crock after antifungal covering application decreases, but it remains within the normal range $-16.2 \%$, which indicates the effect of the astringent CMC on the possibility of clogging the pores of pots' crock because of the dense membrane formation; this membrane has good adhesion and doesn't dissolve rapidly in water. Investigation of the water inpermeability index of pots' crock shows that wet trace on the side wall appears after 23 hours in pot sample without applying antifungal covering; wet trace on the side wall appears after 25 hours in pot sample with antifungal covering on the base of CMC with "Fundazol". It indicates that the antifungal covering forms membrane which protects the porous walls of the ceramic pot from water infiltration, but this membrane has the ability to gradually dissolving.

After research the compliance of the pots with antifungal covering on the base of CMC with "Fundazol" with the requirements of the normative documentation on heat resistance [40] it is noted that the sample with antifungal covering has high resistance to high temperatures: noticeable cracks in the antimicrobial covering appear only after the temperature increasing to $150{ }^{\circ} \mathrm{C}$ on samples which were stored during 12 months. The rational storage period of pots with antifungal covering is 9 months on the based of obtained results.

The effectiveness of glue mixtures samples was checked at the next stage of the work. For this purpose, the soil is infected with vascular wilt (Fusarium oxesporum), was placed in the test pot, after which the contaminated soil was watered with settling water during 6 months and the changes of Fusarium oxesporum fungal germs in the soil were observed by microbiological researches (similar to the previous one). Decreasing of Fusarium oxesporum fungal germs number in the soil was observed during the experiment. The data are presented in fig. 4 prove this fact [43].

As it can be seen from data of fig. 4 the number of fungal germs in the soil was the largest during the first study. The number of fungal germs began to decrease three weeks later. The number of fungal germs significantly decreased after 12 weeks (more than in four times as compared to the 


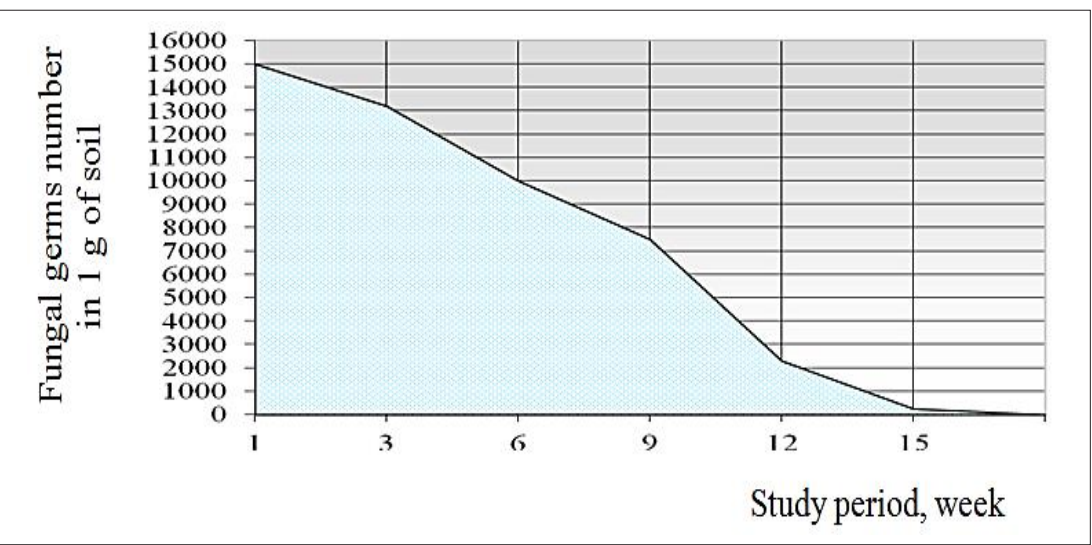

Fig. 4. The study of dynamics of Fusarium oxesporum fungal germs number decreasing in the soil

initial contamination). Fusarium oxesporum fungal germs were not almost identified during the last study.

The visual observation of pots with antifungal action ability to neutralize pathogens of fungal diseases of potted plants is conducted along with microbiological studies. Cyclamen is affected by fungus Fusarium oxesporum was chosen for the research. It has such disease symptoms: the yellowing of leaves, which begins with the tops, is external onset of the disease. Yellowing and fading were observed on one side of the plant. The other side of Cyclamen continued its growth, but without flowering. The affected plant with the above-described symptoms of fusariosis was planted in pot treated with antifungal covering on the base of glutinous mixture of CMC and "Fundazol", after which periodic watering of the plant was carried out. Three months later, significant improvement in the state of the plant was noted. The affected side of the plant could not be saved. Since fusariosis is treated at the initial stages, but yellowing and fading of new leaves were not observed; the growth of the poor crop side increased. The plant almost completely renewed its state after 15 weeks.

It is established that treating of the interior surface of ceramic pots with glutinous mixtures of antifungal action on the base of antifungal preparation "Fundazol" and CMC, in the form of closed strips of $1,5 \mathrm{~cm}$ wide and thickness of $1,5-2 \mathrm{~cm}$, provides obtaining pots for flowers with antifun- 
gal covering, which promotes not only the implementation of preventive action against the soil causative agents of diseases of potted plants, but also the neutralization of contaminated by vascular wilt (Fusarium oxesporum) causative agents soils; which is proved by microbiology studies on the example of Cyclamen house plant. It is determined that pots with antifungal covering which is economically applied meet the quality standards (crock porosity is $16,2 \%$, heat resistance is up to $150{ }^{\circ} \mathrm{C}$ without covering cracking) and have recommended shelf life of 9 months at humidity of 70-75\% and temperature of $18 \pm 2{ }^{\circ} \mathrm{C}$.

\section{Conclusions}

1. The method of obtaining products for cultivation of floral products with antimicrobial covering is proposed and the possibility of realizing the hypothesis of antimicrobial medium creating, which helps protecting or preventing the emergence and reproduction of fungal and microbial diseases is proved.

2. The principle of formation of such medium as new antimicrobial covering on the base of mixture of water-soluble substance and preparations with prophylactic and therapeutic effects on pathogens of fungal and microbial potted plants diseases is developed and proved.

3. The selection of mixture components which have effective action, don't significantly affect on the product's price increasing and can be used in the technological process of producing flower and decorative goods without significant changes is carried out.

4. The method of applying of new antimicrobial covering to the interior surface of flower pots in the form of solid layer or closed strips of $1,5 \mathrm{~cm}$ wide and 1,5-2 cm thickness is presented.

5. It is shown that pots with developed antimicrobial and antifungal covering meet the standards according to quality indices (crock porosity, water absorption, heat resistance) and have the recommended shelf life of 6 and 9 months, respectively, at humidity of $70-75 \%$ and temperature of $18 \pm 2{ }^{\circ} \mathrm{C}$.

6. It is experimentally proved (on the example of plants (Cyclamen and Begonia $x$ elatior) cultivation and microbiological studies of the soil) that the treatment of the interior surface of ceramic pots with antimicrobial covering provides not only the implementation of preventive action against the soil causative agents of plant diseases, but also the neutralization of 
pathogens of fungal diseases in contaminated soils and gradual renewal of the decorative state of plants.

The next stage of experimental research is planned to be carried out in the field of proving the possibility of treatment with antimicrobial mixtures of a number of other products for cultivation and decorating of in hothouses plants.

\section{References:}

1. Vysotskyi A.L., Bodnar A.V., Dzelendziak Yu.A. (2012) Lohistyka kvitiv v Ukraini [Logistics of flowers in Ukraine]. Lviv Polytechnic National University Institutional Repository. Retrieved from http://ena.lp.edu.ua:8080/bitstream/ ntb/16007/1/6-Vysotsky-34-37.pdf

2. Shvahuliak-Shostak O. (2007) Mystetstvo ne potrebuie zhertv [Art doesn't demand the victims]. Magazine Contacts, no. 37, pp. 23-25.

3. Solomakha I.V. (2012) Osoblyvosti funktsionuvannia vitchyznianoho rynku produktsii kvitnykarstva [Features of functioning of the domestic market of production of floriculture]. Bulletin of the Ternopil national economic university, no. 3 , pp. 33-41.

4. Moroz I.I. (1984) Tekhnologiya farforo-fayansovikh izdeliy. [Technology farforo-fayansovikh of products]. Moscow: Stroyizdat. (in Russian)

5. Khodykin A.P., Liashko A.A., Voloshko N.I., Snytko A.P. (2006) Tovaroznavstvo neprodovolchykh tovariv [Merchandizing of nonfoods]. Moscow: Dashkov and K. (in Russian)

6. Kardash V.Ya., Pavlenko I.A. (2002) Tovarna innovatsiina polityka [Commodity innovative policy]. Kiev: Kiev national economic university. (in Ukrainian)

7. Sorokina S.V., Zakharenko V.O., Diakov O.H. (2013) Patent 84961 Ukraine, A01G 9/01. Syhnalizator dlia pidtrymky optymalnoi volohosti gruntu v kvitkovykh horshchykakh [Signaling device for maintenance of optimum humidity of the soil in flowerpots], No u201304254; stated 20.08.2013; posted. 11.11.2013; bulletin No. 20.

8. Chuchkin V.G., Legkov S.E., Fedotova L.V., Iordan A.G. (1996) Patent $2070782 \mathrm{RF}, \mathrm{A} 01 \mathrm{G}$ 9/02. Ustroystvo dlya vyrashchivaniya rasteniy s avtomaticheskim uvlazhneniem pochvy [The device for cultivation of plants with automatic moistening of the soil], stated 30.05.1994; posted. 27.12.1996.

9. Ignatenko V.V, Sel'kov V.K. (1992) Patent 1706461 SSSR, A01G 9/02. Gorshok dlya tsvetov [Flower pot], No 4311631/15; stated 25.08.1987; posted. 23.01.1992; bulletin No. 3 .

10. Shchepochkina Yu.A. (2008) Patent 2327340 RU, A01G 9/02. Gorshok dlya tsvetov [Flower pot], stated 27.10.2006; posted. 27.06.2008. Retrieved from http://www.findpatent.ru/patent/232/2327340.html

11. Akhmedov Yu. (1986) Patent 1454311 SSSR, A01G 9/02. Sposob izgotovleniya korneobitaemogo pologo gorshochka [Way of production of a korneobitayemy hollow pot], No 4073491/30-15; stated 16.04.86; posted. 30.01.86; bulletin No. 4. 
12. Vinogradov A.V. Patent 2086102 RU, A01G 9/02, A01G31. Sposob vyrashchivaniya rasteniy i ustroystvo dlya vyrashchivaniya rasteniy [Way of cultivation of plants and the device for cultivation of plants]. Retrieved from http://www.findpatent.ru/patent/208/2086102.html

13. Sevelev N.V., Konovich A.Ya., Dragunov I.A. (1986) Patent 961174 SSSR, A01G 9/02. Ustroystvo dlya proizvodstva gorshochkov [The device for production of pots], No 2938821/30-15; stated 06.06.80; posted. 07.10.86; bulletin No. 37.

14. Makarov A.N., Makarov A.A. (1994) Patent 2010492 RF, A01G 9/02. Gorshok dlya vyrashchivaniya rasteniy [Pot for cultivation of plants], No 4937927/15; stated 28.03.91; posted. 15.04.94; bulletin No. 7.

15. Vokhmyanin V.G. (1994) Patent 2011335 RF, A01G 9/02. Tsvetochnyy gorshok [Flowerpot], No 5028935/15; stated 25.02.92; posted. 30.04.94; bulletin No. 8 .

16. Ivanova G.A. (1991) Patent 1692383 SSSR, A01G 9/02. Razbornoy tsvetochnyy gorshok [Folding flowerpot], No 47110799/15; stated 28.06.89; posted. 23.11.91; bulletin No. 43.

17. Anokhina O.O., Sorokina S.V. (2007) Doslidzhennia spozhyvchykh vlastyvostei keramichnykh vyrobiv [Research of consumer properties of pottery]. Proceedings of the Sotsium. Nauka. Kultura: II Vseukrainska naukovo-praktychna Internet-konferentsiia (Ukraine, Kiev, on January 29-31, 2007), Kiev: Meganom, part 2, pp. 61-63.

18. Musiienko M.M. (2001) Fiziolohiia roslyn [Phytophysiology]. Kiev: Fitosotsiocentre. (in Ukrainian)

19. Kefeli V.I. (1991) Fiziologiya rasteniy s osnovami mikrobiologii [Physiology of plants with fundamentals of microbiology]. Moscow: Agropromizdat. (in Russian)

20. A. Yousser, K.A. El-Tarabily, A.M. Hussen (2001) Pletosporium tabacium root rot disease of white lupiand its biological control by Streptomyces spicies. Phytopathol Journal, vol. 1, no. 149, pp. 29-33.

21. Rukavitsina I.V. Nechay N.L., Karamshuk Z.P. (2008) Fungitsidnoe deystvie vodnykh vytyazhek vysshikh rasteniy na morfologiyu gribov roda fusarium [Fungicide action of water extracts of the higher plants on morphology of mushrooms of the sort fusarium]. Proceedings of the Sovremennaya mikologiya v Rossii: II s"ezd mikologov Rossii (Russia, Moscow, on April 18, 2008), Moscow: National academy of a mikotologiya, pp. 299-300.

22. Trybel S.O. Stryhun O.O. (2013) Zakhyst roslyn - realnyi napriam zbilshennia vyrobnytstva roslynnytskoi produktsii [Protection of plants - the real direction of increase in production of crop production]. Zakhyst $i$ karantyn roslyn, mizhvidomchyi tematychnyi naukovyi zbirnyk [Protection and quarantine of plants, interdepartmental thematic scientific collection]. Kiev: Institute of protection of plants of National academy of agrarian sciences of Ukraine, no. 59, pp. 324-336.

23. Primenenie fungitsidov [Use of fungicides]. Retrieved February 20, 2018, from https://iplants.ru/preparats3.htm

24. Sorokina S.V, Talaieva O.V. (2012) Doslidzhennia orhanoleptychnykh pokaznykiv ta pokaznykiv bezpechnosti keramichnykh vyrobiv dlia kvitiv [Research of organoleptic indicators and indicators of safety of pottery for flowers]. Proceedings 
of the Aktualni problemy rozvytku kharchovykh vyrobnytstv, hotelnoho, restorannoho hospodarstv i torhivli: vseukrainska naukovo-praktychna konferentsiia molodykh vchenykh i studentiv (Ukraine, Kharkiv, on April 25, 2012), Kharkiv: Kharkiv state university of food and trade, part 2, pp. 24.

25. Shuvalov V.N. (2018) Fungitsidy dlya komnatnykh rasteniy: vidy i nazvaniya [Fungicides for houseplants: types and names]. Retrieved February 20, 2018, from https://klumba.guru/uhod-za-rasteniyami/fungicidy-dlya-komnatnyh-rasteniy-vidy-i-nazvaniya.html\#hcq=NmGzmJq

26. Ganichkina O. (ed.) (2001) Bol'shaya kniga sadovoda i ogorodnika [Big book by the gardener and gardener]. Moscow: New wave. (in Russian)

27. Tabolkin D., Vasil'eva E., Pernat'ev Yu. (2010) Komnatnoe tsvetovodstvo [Room floriculture]. Kiev, Folio. (in Ukrainian)

28. Mudretsova-Viss K.A., Kudryashova A.A., Dedyukhina V.P. (2001) Mikrobiologiya, sanitariya $i$ gigiena [Microbiology, sanitation and hygiene]. Moscow: Business literature. (in Russian)

29. Cherkes F.K., Bel'skaya N.A., Bogoyavlenskaya L.B. (1986) Sanitarnobakteriologicheskoe issledovanie pochvy [Sanitary and bacteriological research of the soil]. Mikrobiologiya [Microbiology]. Moscow: Medicine, pp. 385-402.

30. Sorokina S.V., Horbenko O.O. (2008) Rozrobka dodatkovykh vlastyvostei keramichnykh horshchykiv dlia kvitiv [Development of additional properties of ceramic flower pots]. Visnyk Natsionalnoho tekhnichnoho universytetu "Kharkivskyi politekhnichnyi instytut": Zburnyk naukovykh prats. Tematychnyi vypusk "Khimiia, khimichna tekhnolohiia ta ekolohiia" [Bulletin of the National technical university "Kharkiv Polytechnical Institute": Collection of scientific works. Thematic release "Chemistry, chemical technology and ecology"]. Kharkiv: National technical university "Kharkiv Polytechnical Institute", no. 10, pp. 82-84.

31. Sorokina S.V., Karpenko Z.P., Ivanova A.A. (2007) Do pytannia nadannia keramichnym horshchykam dlia kvitiv dodatkovykh spozhyvchykh vlastyvostei [To a question of providing additional consumer properties to ceramic flower pots]. Proceedings of the Rozvytok naukovykh doslidzhen - 2007: mizhnarodna naukovo-praktychna konferentsiia (Ukraine, Poltava, on November 26-28, 2007), Poltava: Inter-graphics, no. 10, pp. 103-105.

32. Tarasenko O.S., Sorokina S.V. (2010) Ekspertyza yakosti ta napriamy polipshennia pozhyvnykh vlastyvostei keramichnykh horshchykiv dlia kvitiv [Examination of quality and direction of improvement of consumer properties of ceramic flower pots]. Proceedings of the Ekspertna diialnist v mytnii spravi: problemy ta perspektyvy: Vseukrainska konferentsiia studentiv i molodykh vchenykh (Ukraine, Donetsk, on April 6, 2010), Donetsk: Donetsk national university of economy and trade, pp. 282-284. 